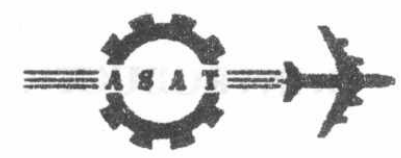

$7^{\text {th }}$ INTERNATIONAL CONF. ON AEROSPACE SCIENCES \& AVIATION TECHNOLOGY

\title{
CORROSION RESISTANCE AND SURFACE TOPOGRAPHY OF ELECTRODEPOSITED Zn-Ni-Fe ALLOY
}

\author{
O. A. FADALI*, Ibrahium Hamed M. ALY*, M. M. YOUNAN**, \\ M. A. ARAFA***, A. T. EL-MALLAH*** and T. OKI*****
}

\begin{abstract}
In electroplating of ternary $\mathrm{Zn-Ni-Fe}$ alloy from the acidic chloride baths, the influence of iron codeposition on corrosion resistance and surface topography of the electrodeposits were investigated in comparison with $\mathrm{Zn}-\mathrm{Ni}$ alloy deposits. It was found that the ternary $\mathrm{Zn}-\mathrm{Ni}-\mathrm{Fe}$ alloy showed better corrosion resistance in comparison with binary $\mathrm{Zn}$ $\mathrm{Ni}$ alloy, even though both $\mathrm{Zn}-\mathrm{Ni}-\mathrm{Fe}$ and $\mathrm{Zn}-\mathrm{Ni}$ deposits contained approximately the same nickel content. The best corrosion resistance, in 3\% neutral sodium chloride solution, observed from the deposit having $16.74 \%$ nickel and $3.95 \%$ iron. The surface topography of the deposits was characterized by using scanning electron microscopy (SEM) in order to give more information about corrosion behaviors. It was found that the deposits with iron had finer grain size and more homogenous structure in contrast to that of $\mathrm{Zn}-\mathrm{Ni}$ deposits.
\end{abstract}

\section{KEY WORDS}

Electrodeposition, $\mathrm{Zn}-\mathrm{Ni}-\mathrm{Fe}$ alloy, $\mathrm{Zn}-\mathrm{Ni}$ alloy, Surface topography, Corrosion.

* Professor, Dpt. of Chemical Engineering, Faculty of Engineering, El-Minia University, Egypt. ** Graduate student, Dpt. of Chemical Engineering and Pilot Plant, National Research Centre, Giza, Egypt. *** Professor, Dpt. of Chemical Engineering and Pilot Plant, National Research Centre, Giza, Egypt. **** Professor, Dpt. of Materiais Science and Engineering, Faculty of Engineering, Nagoya University, Japan. 


\section{INTRODUCTION}

Numerous changes in characteristic have taken place in the production of zinc coatings on steel and many efforts have been made to improve the corrosion resistance using multilayered electrogalvanizing coatings [1-3], composite zinc films [47] and, especially, zinc alloy coatings [8-15]. Increasing interest has been directed towards zinc-iron [7,9] and, especially, zinc-nickel [10-15] alloy coatings that appeared to be particularly attractive since these deposits exhibit better physical and electrochemical properties than a pure zinc layer. The electrodeposition of zinc-nickel alloy is a codeposition of anomalous type according to the definition of Brenner [16]; that is the less noble metal deposited preferably on the cathode with respect to the more noble one.

Various electrolytes have been reported for the electrodeposition of $\mathrm{Zn}-\mathrm{Ni}$ alloys. However most of the published work concerns the electrodeposition from sulfate or chloride baths. A Boeing process has been described by Hsu [15] for deposition of $\mathrm{Zn}$-Ni alloys from a non cyanide chloride bath. Most of the authors pointed out that the best corrosion resistance behavior is exhibited by electrodeposited $\mathrm{Zn}-\mathrm{Ni}$ alloys containing 10-20\% of nickel, because they consist of a single phase structure ( $\gamma$ phase).

This report is an extension for our investigations on the electrodeposition of $\mathrm{Zn}-\mathrm{Ni}-\mathrm{Fe}$ alloys to study the corrosion behavior of these deposits in comparison with $\mathrm{Zn}-\mathrm{Ni}$ deposits. The study, also, included the surface topography of both $\mathrm{Zn}-\mathrm{Ni}-\mathrm{Fe}$ and $\mathrm{Zn}-\mathrm{Ni}$ deposits.

\section{EXPERIMENTAL PROCEDURE}

In order to study the surface topography and corrosion resistance of $\mathrm{Zn}-\mathrm{Ni}$ - $\mathrm{Fe}$ and $\mathrm{Zn}$ $\mathrm{Ni}$ deposits, these deposits were prepared on mild steel plates using the process of separated anodes, as explained in our previous paper. Also, both $\mathrm{Zn}-\mathrm{Ni}-\mathrm{Fe}$ and $\mathrm{Zn}-\mathrm{Ni}$ deposits were produced under constant conditions (at $30 \mathrm{mAcm}^{-2}, 43{ }^{\circ} \mathrm{C}$ and $\mathrm{pH} 3$ ), in order to get the same nickel content in these deposits.

The surface topography of the deposits was examined by using scanning electron microscopy (SEM). The samples for aqueous corrosion testing were mounted in an electrode holder which exposed one $\mathrm{cm}^{2}$ of the sample area to the electrolyte. Electrolytes were made using distilled water and reagent grade sodium chloride. The sample holder was inserted in an electrochemical cell for potentiodynamic and potentiostatic corrosion experiments. For potentiodynamic testing, an anodic over-potential was added and the resulted current density 
was recorded. Corrosion experiments were performed at room temperature $\left(23\right.$ to $\left.25^{\circ} \mathrm{C}\right)$. The reference electrode was saturated calomel electrode (SCE) and the counter electrode was platinum wire.

\section{RESULTS AND DISCUSSION}

\section{1) Surface Topography}

Concomitant changes in the structure, as found from X-ray diffraction analysis through our previous work, can observed by SEM analysis. Figures 1 and 2 show the surface topography of the deposits containing different percentages of nickel and iron contents.

The $\mathrm{Zn}$-Ni deposits showed a homogeneous structure formed of crystallites with columnar growth of pyramidal form; these grains size are slightly finer with increasing nickel content from $14.17 \%$ to $17.26 \%$ as shown from case (a) in Figs. 1 and 2. While with iron codeposition, the ternary $\mathrm{Zn}-\mathrm{Ni}$-Fe alloys still show a pyramidal columnar structure, but the grain size is very fine and more homogeneous in comparison with those of binary $\mathrm{Zn}-\mathrm{Ni}$ deposits, as shown in Figs. 1 and 2.

For instance, the binary $\mathrm{Zn}-\mathrm{Ni}$ deposits that contained ( $14.17 \%$ nickel) had course grain size than those of $\mathrm{Zn}-\mathrm{Ni}$ that contained (17.26\% nickel), as shown in Figs. 1(a) and 2(a), respectively. However, the ternary $\mathrm{Zn}-\mathrm{Ni}-\mathrm{Fe}$ that contained ( $13.92 \% \mathrm{Ni}$ and $2.64 \% \mathrm{Fe}$ ) had finer grain size and more homogeneous in comparison with those of binary $\mathrm{Zn}$-Ni that contained $(17.26 \% \mathrm{Ni})$, as shown in Figs. $1(\mathrm{c})$ and $2(\mathrm{a})$, respectively. Iron deposits better with increasing ferrous ion concentration in the baths as absorbent to inhibit the crystal growth, and the nucleation may occur a little frequently without iron in bath. Then the grain size obtained in baths with iron becomes finer than that without iron.

\section{2) Corrosion Resistance}

The corrosion behavior of electrodeposited $\mathrm{Zn}-\mathrm{Ni}$ thin films bas been studied from an electrochemical stand point by Kurachi et al. [17]. They measured the corrosion potentials ( $E_{\text {corr. }}$ ) over the full range of $\mathrm{Zn}-\mathrm{Ni}$ alloy compositions in a sulfate bath. Their results showed that the corrosion potentials become more negative with increasing $\mathrm{Zn}$ content until the $\gamma+\eta$ phase alloy was reached. The corrosion resistance of electrodeposited $\mathrm{Zn}-\mathrm{Ni}$ alloys was studied, also, by $[17,18,19]$ and they concluded that the best corrosion resistance of these 
alloy coatings was obtained from the deposits containing $11-18 \% \mathrm{Ni}$, because these alloys contained a single $\gamma$ phase alloy.

In the present work, the corrosion potentials $\left(E_{\text {corr. }}\right)$ vs. SCE were measured; as for different compositions of $\mathrm{Zn}-\mathrm{Ni}-\mathrm{Fe}$ deposits, after four minutes dipping in $3 \%$ neutral sodium chloride solution. Table 1 shows the results of the influence of iron codeposition on the ( $\left.E_{c o r r}\right)$ of the deposits. The results may be summarized as follows: (1) the $E_{c o r r}$ of the deposits without iron shifted to the positive direction (from -1350 to $-1247 \mathrm{mV}$ ) with increasing of $\mathrm{Ni}$ content (from $15 \%$ to $17.26 \% \mathrm{Ni}$, respectively); (2) the deposits with iron codeposition have nobler $\mathrm{E}_{\text {corr. }}$ in comparison with Ecorr. of the $\mathrm{Zn}-\mathrm{Ni}$ deposits (having approximately the same $\mathrm{Ni}$ content). From group $\mathrm{D}$ in Table 1 , the $\mathrm{E}_{\text {corr. }}$ of only $\mathrm{Zn}-\mathrm{Ni}$ deposits shifted to more positive direction (from -1247 to $-1135 \mathrm{mV}$ ) with iron codeposition and (3) the $\mathrm{E}_{\text {corr. }}$ of $\mathrm{Zn}-\mathrm{Ni}-\mathrm{Fe}$ deposits approximately did not changed with increasing $\mathrm{Fe}$ content, as shown in group $\mathrm{D}$ of Table 1.

Table 1. The corrosion potential ( $E_{\text {corr. }}$ ) of the deposits after four minutes dipping in neutral 3 wt\% sodium chloride solution.

\begin{tabular}{|c|c|c|c|c|c|}
\hline \multirow{2}{*}{$\begin{array}{c}\text { Alloy } \\
\text { No. }\end{array}$} & \multirow{2}{*}{$\begin{array}{l}\text { Alloy } \\
\text { Type }\end{array}$} & \multicolumn{3}{|c|}{ Deposit analysis, wt\% } & \multirow{2}{*}{ 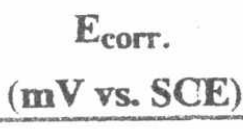 } \\
\hline & & $\mathbf{Z n}$ & $\mathbf{N i}$ & $\mathrm{Fe}$ & \\
\hline \multirow{2}{*}{ A. $\begin{array}{r}1 \\
2 \\
\end{array}$} & $\mathrm{Zn}-\mathrm{Ni}$ & 85.83 & 14.17 & 0.00 & -1365 \\
\hline & $\mathrm{Zn}-\mathrm{Ni}-\mathrm{Fe}$ & 83.27 & 14.60 & 2.13 & -1290 \\
\hline \multirow{2}{*}{ B. 1} & $\mathrm{Zn}-\mathrm{Ni}$ & 85.26 & 14.74 & 0.00 & -1355 \\
\hline & $\mathrm{Zn}-\mathrm{Ni}-\mathrm{Fe}$ & 83.44 & 13.92 & 2.64 & -1260 \\
\hline \multirow{2}{*}{ C. 1} & $\mathrm{Zn}-\mathrm{Ni}$ & 84.99 & 15.01 & 0.00 & -1350 \\
\hline & $\mathrm{Zn}-\mathrm{Ni}-\mathrm{Fe}$ & 82.44 & 15.08 & 2.48 & -1260 \\
\hline \multirow{5}{*}{ D. } & $\mathrm{Zn}-\mathrm{Ni}$ & 82.74 & 17.26 & 0.00 & -1247 \\
\hline & $\mathrm{Zn}-\mathrm{Ni}-\mathrm{Fe}$ & 81.69 & 16.84 & 1.47 & -1140 \\
\hline & $\mathrm{Zn}-\mathrm{Ni}-\mathrm{Fe}$ & 81.51 & 15.91 & 2.58 & -1135 \\
\hline & $\mathrm{Zn}-\mathrm{Ni}-\mathrm{Fe}$ & 7931 & 16.74 & 3.95 & -1140 \\
\hline & $\mathrm{Zn}-\mathrm{Ni}-\mathrm{Fe}$ & 78.50 & 16.30 & 5.20 & -1130 \\
\hline
\end{tabular}

To make a clear comparison for corrosion resistance of both $\mathrm{Zn}-\mathrm{Ni}$ and $\mathrm{Zn}-\mathrm{Ni}-\mathrm{Fe}$ deposits, the corrosion behavior was measured by polarization resistance method. Figures 3 to 6 show the potentiodynamic polarization data for the deposits in $3 \%$ neutral $\mathrm{NaCl}$. From curve 1 in these figures, it can be seen that the polarization resistance of $\mathrm{Zn}-\mathrm{Ni}$ deposits lincreases with increasing of $\mathrm{Ni}$ content. 
Under the same plating conditions, it has been found that the polarization resistance of $\mathrm{Zn}-\mathrm{Ni}-\mathrm{Fe}$ deposits is higher than that of $\mathrm{Zn}-\mathrm{Ni}$ deposits. Figure 3, for example, illustrated the polarization resistance of the deposits as a function of iron content. From this figure, the polarization resistance of $\mathrm{Zn}-\mathrm{Ni}-\mathrm{Fe}$ deposits (curves 2 to 5 ) is higher in comparison with that of $\mathrm{Zn}-\mathrm{Ni}$ alloy (curve 1). The passive region of $\mathrm{Zn}-\mathrm{Ni}-\mathrm{Fe}$ deposits is slightly increased with increasing of iron content in the alloy up to $3.95 \%$.

For $\mathrm{Zn}-\mathrm{Ni}-\mathrm{Fe}$ deposit; the passive region extended from the rest potential to approximately $-1100 \mathrm{mV}$ and the current density (at $-1100 \mathrm{mV}$ ) was of $0.05 \mathrm{mAcm}^{-2}$ (curve 4 in Fig. 3). On the other hand; the passive region of $\mathrm{Zn}-\mathrm{Ni}$ deposit extended from the rest potential to approximately $-1180 \mathrm{mV}$ and the current density (at $-1180 \mathrm{mV}$ ) was of 0.1 $\mathrm{mAcm}^{-2}$ (curve 1 in Fig. 3).

The increase in corrosion resistance of $\mathrm{Zn}-\mathrm{Ni}-\mathrm{Fe}$ alloys is not only due to the formation of a single high nickel $\gamma$ alloy phase but also due to codeposition of iron. Codeposition of iron changed the $\gamma$ phase structure to prefer (442), (600) and/or (444) orientation instead of (330) and (411) orientation of Zn-Ni alloy. Also, iron codeposition in the alloy tends to produce a finer grain size and increases in the lattice space of crystals as already observed by SEM and X-ray diffraction analysis.

\section{CONCLUSION}

SEM showed that the grain size of ternary $\mathrm{Zn}-\mathrm{Ni}-\mathrm{Fe}$ alloys was finer and more homogeneous in comparison with those of binary $\mathrm{Zn}-\mathrm{Ni}$ alloys. The ternary $\mathrm{Zn}-\mathrm{Ni}-\mathrm{Fe}$ alloys had better corrosion resistance than binary $\mathrm{Zn}-\mathrm{Ni}$ alloys and the best corrosion resistance was observed from the deposit containing $16.74 \% \mathrm{Ni}$ and $3.95 \% \mathrm{Fe}$. The increase in corrosion resistance of ternary deposits is not only attributed to formation of single high nickel $\gamma$ phase but also due to iron codeposition, which causes clearly change of crystal orientation with increases in the lattice space of crystals and obtains finer grain size with addition of iron.

\section{REFERENCES}

[1] A. Catanzaro et al., SAE Tech. Pap. Series No. 830583, Detroit, Michigan (1983).

[2] M. Memmi, R. Bruno and M. Palladino, Mater. Perform, 2 (1983) 9.

[3] S. Kado, S. A. Yusawa and T. Watanabe, Tetsu to Hagane, 66 (1980) 790.

[4] T. Adaniya, Sheet Metal Ind, Int, 12 (1978) 73.

[5] K. Ariga and K. Kanda, Tetsu to Hagane, 66 (1980) 797. 
[6] T. Adaniya, M. Omura, K. Matsudo and H. Naemura, Pat. Surf. Finish., 68 (1981) 96.

[7] K. Higasshi et al., J. Electrochem. Soc., 128 (1981) 2081.

[8] T. Fukuzuka, K. Jajiawara and K. Miki, Tetsu to Hagane, 66 (1980) 807.

[9] T. Watanabe etal., SAE Tech. Pap. Series No 820424, Detroit, Michigan (1982).

[10] A. Shibuya et al., Tetsu to Hagane 66 (1980) 771.

[11] R. Noumi et al., SAE Tech. Pap. Series No 820332, Detroit, Michigan (1982).

[12] T. Kurimoto et al., SAE Tech. Pap. Series No 831837, Warrendale, Pennsylvania (1983).

[13] V. Raman, et al., Met. Finish., 81 (1983) 85.

[14] D. E. Hall, plat. surf. Finish., 71 (1983) 59.

[15] G. F. Hsu, plat. surf. Finish., 72 (1984) 52.

[16] A. Brenner, "Electrodeposition of Alloys" Vol. 1 \& 2, Academic Press, New York and London (1963).

[17] M. Kurach et al., Proc. Cong. Int. Union Electrodeposition Sur. Finish., N. IbI, ed., P 152 (1973).

[18] T. K. Christman et al.,ILZRO Research Report, ZE286, New Yourk, NY (1980).

[19] D. H. Schantz, U. S. Patent, 2,419,231 (April 22, 1947). 
(a)

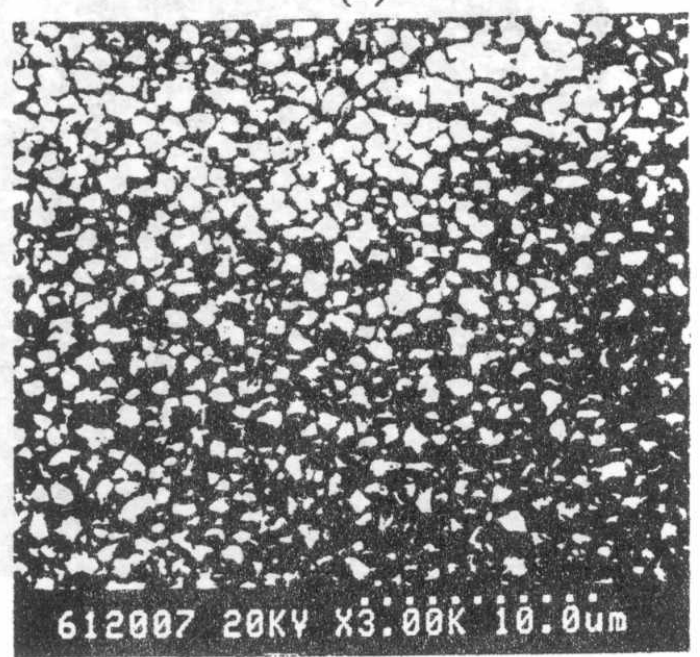

(b)

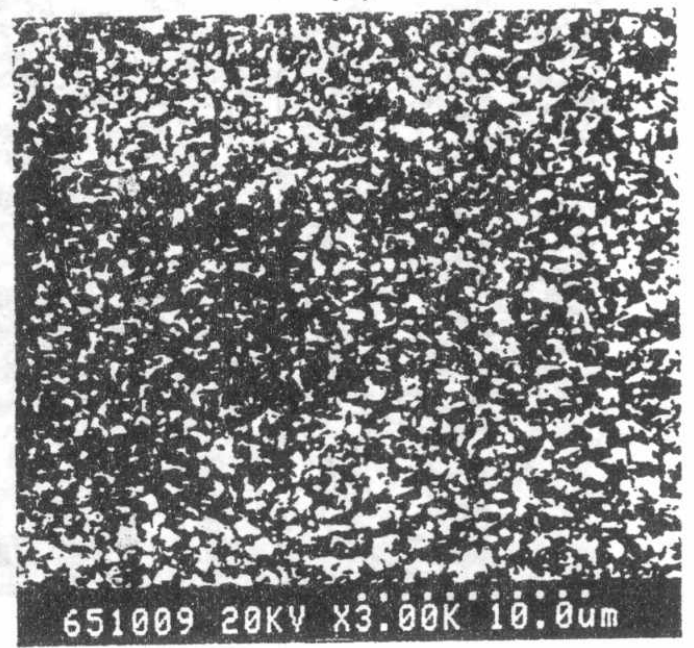

(c)

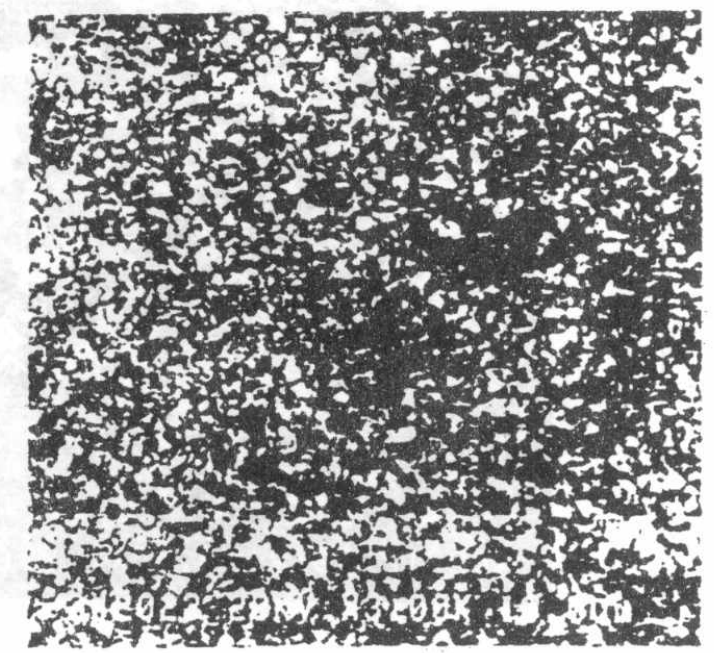

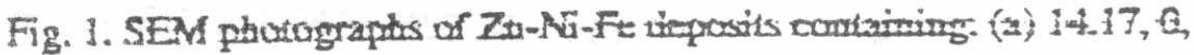

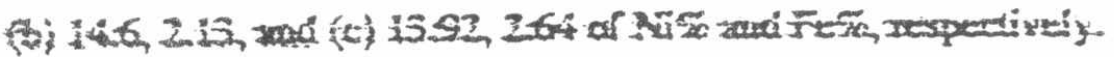


(a)

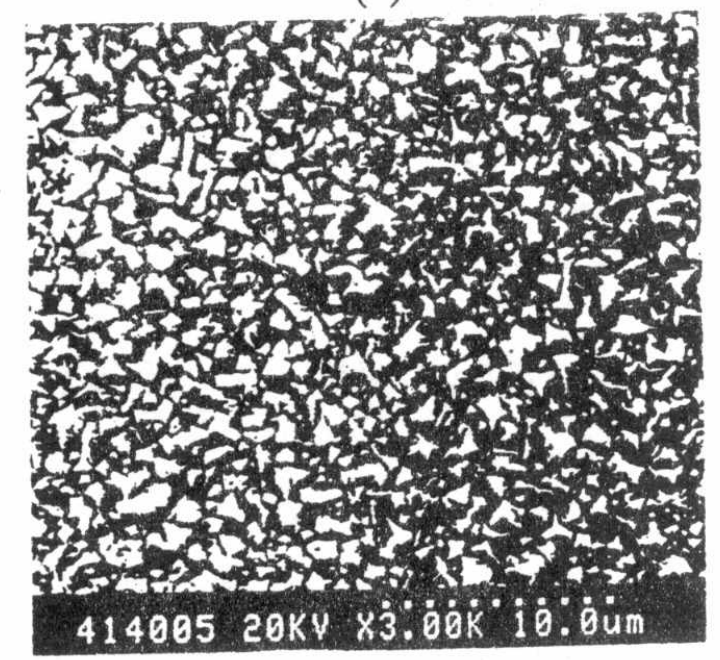

(b)

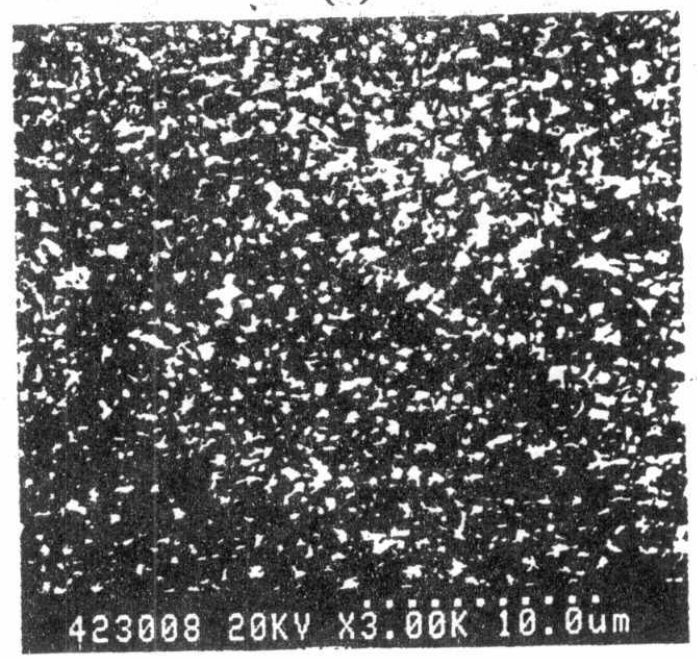

(c)

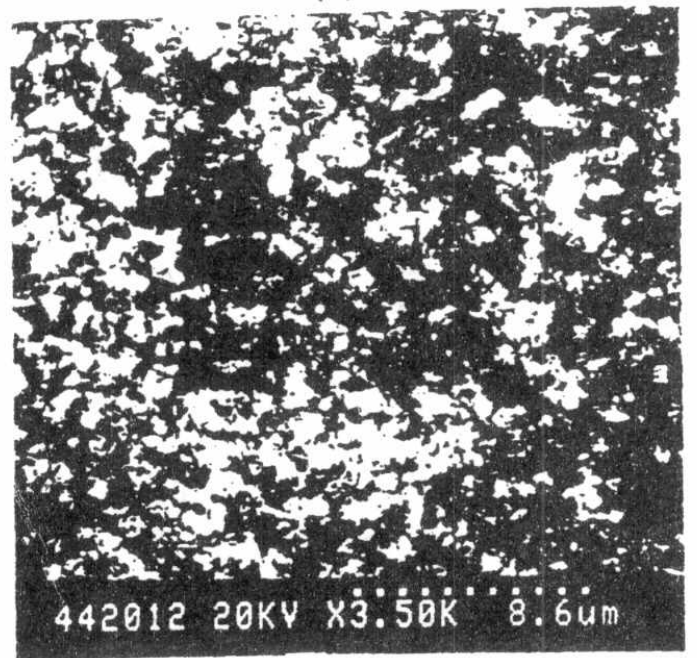

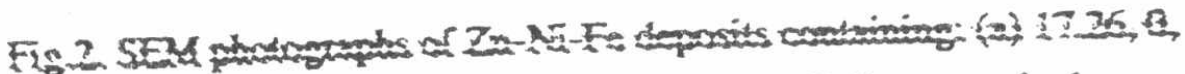

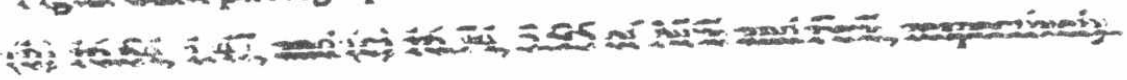




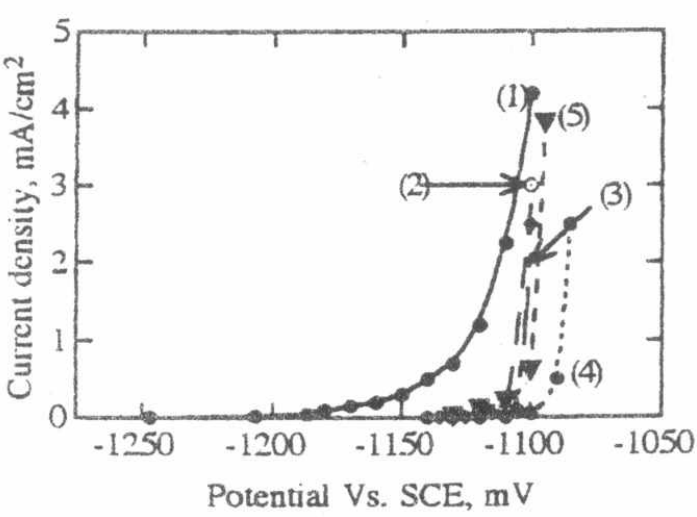

Fig 3. Polarization resistance in netral $3 \% \mathrm{NaCl}$ solution for $\mathrm{Zn}-\mathrm{N} \mathrm{i}-\mathrm{Fe}$ deposits containing: (1) 17.26,0,

(2) $1684,1.47$, (3) $15.91,258$, (4) $16.74,3.95$ and

(5) 163,52 of $\mathrm{Ni} \%$ and $\mathrm{Fe} \%$, respectively.

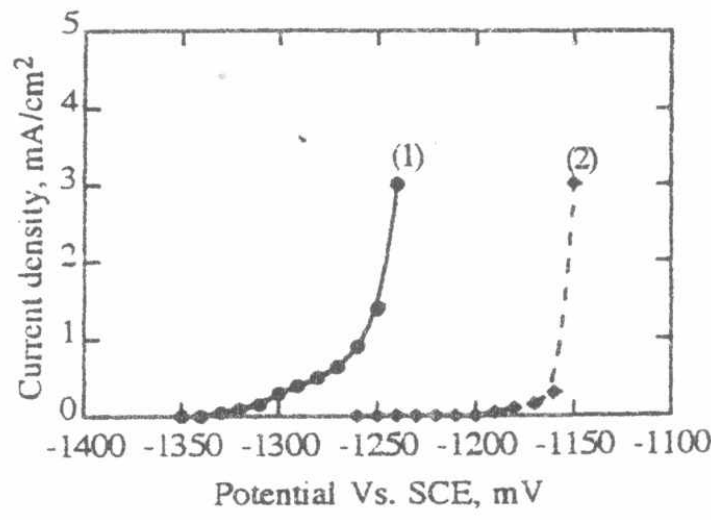

Fig. 4. Polarization resistance in neutral $3 \% \mathrm{NaCl}$ solttion for $\mathrm{Zn}-\mathrm{Ni}$-Fe deposits containing (1) 15.01,0 and (2) 1508,248 of $\mathrm{N} \%$ and $\mathrm{Fe} \%$, respectively.

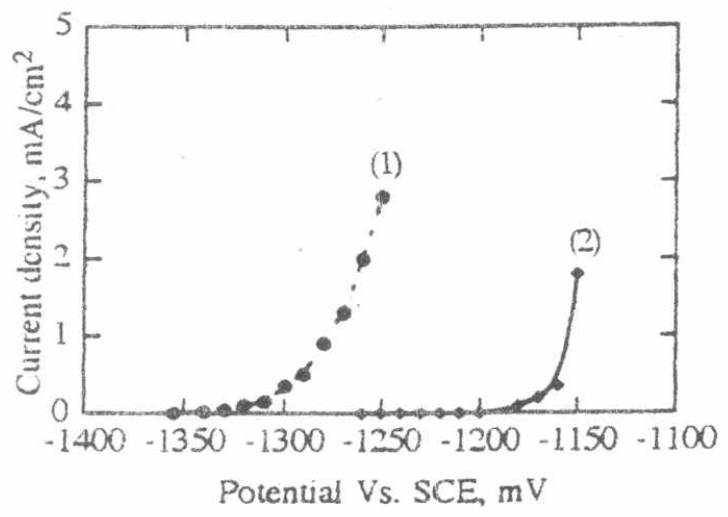

Fig 5. Polarization resistance in neutral $3 \% \mathrm{NaQ}$ solution for $\mathrm{Zn}-\mathrm{Ni}$-Fe deposits containing (1) 14.74,0 and (2) 1392,264 of $\mathrm{Ni} \%$ and $\mathrm{Fe} \%$, respectivedy.

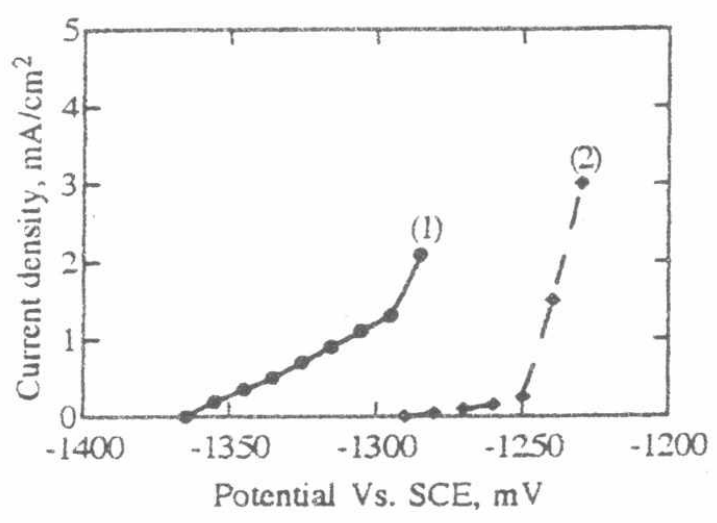

Fig. 6. Polarization resistance in neutral $3 \% \mathrm{Nad}$ solt tion for $\mathrm{Zn}-\mathrm{N}$-Fe deposits oontaining (1) 14.17,0 and (2) 146,213 of $\mathrm{Ni} \%$ and $\mathrm{Fe} \%$, respectively. 